\title{
Onset-inhibition in the auditory brainstem: a potential mechanism for signal enhancement of speech-like sounds
}

\author{
Martin J Spencer ${ }^{1,2,3^{*}}$, David AX Nayagam ${ }^{4,5}$, Janine Clarey ${ }^{4}$, Hamish Meffin ${ }^{2,1,3}$, Anthony N Burkitt ${ }^{2,3,4}$, \\ David B Grayden ${ }^{1,2,3,4}$
}

From Twenty Second Annual Computational Neuroscience Meeting: CNS*2013

Paris, France. 13-18 July 2013

\begin{abstract}
A prominent feature in the ascending auditory pathway is that of broadband onset inhibition, and there are many hypotheses regarding its functional role [1-4]. Here, we examine the possibility that it acts to suppress broadband onset splatter, the inharmonic noise that occurs at the beginning of sharp-onset sounds such as the glottal pulses in speech. We use experimental data from a circuit in the mammalian auditory brainstem formed by octopus cells in the posteroventral cochlear nucleus (PVCN), and their thick-axon projections to the ventral nucleus of the lateral lemniscus (VNLL) ending in calyx synapses. Octopus cells fire action potentials only in response to broadband auditory events, and they reliably stimulate cells located in the VNLL with a short latency. These cells, in turn, provide inhibitory connections to other VNLL cells (here referred to as the "VNLL cells"), which also receive excitatory input from cochlear nucleus $(\mathrm{CN})$ cells [5]. We used a leaky integrate-and-fire (LIF) neuron model with experimentally constrained parameters to recreate the behavior of the circuit. The input to the model was provided by an existing auditory periphery model. A metric, the carrier clarity quotient (CCQ) was devised to quantify the signal strength of the carrier when modulated by a saw-tooth temporal envelope. This envelope is similar to that of glottal pulses in speech. It was observed that, at a certain relative delay between the excitatory and inhibitory input to the VNLL cells, the CCQ associate with a population of VNLL cells exceeded that of a comparable population of auditory nerve fibres (Figure 1).
\end{abstract}

\footnotetext{
* Correspondence: martyspence@gmail.com

'NeuroEngineering Laboratory, Dept of Electrical \& Electronic Engineering, University of Melbourne VIC 3010, Australia

Full list of author information is available at the end of the article
}

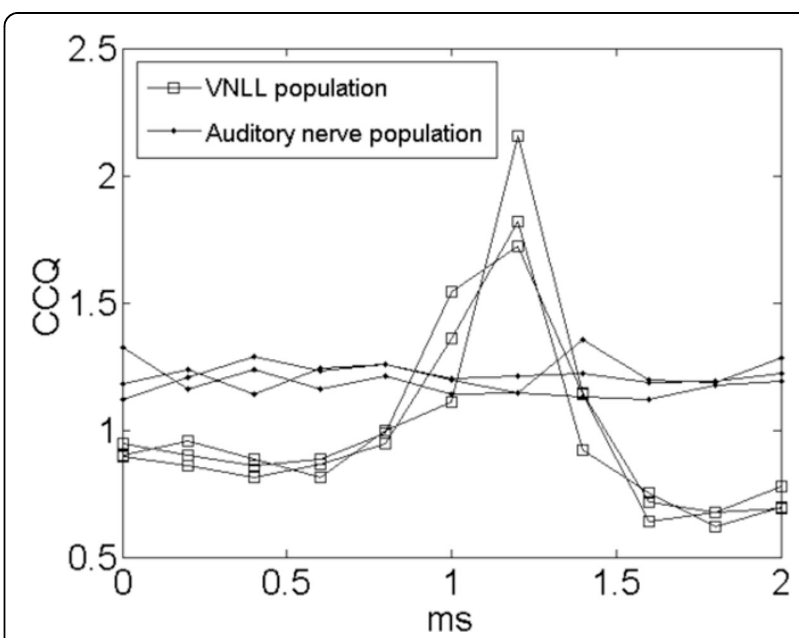

Figure 1 The carrier clarity quotients for a modeled population of primary-like cells and Cell-C cells as a function of the relative delay between excitation and inhibition in the Cell-C population. Three trials are plotted.

\section{Conclusion}

Onset inhibition in the auditory brainstem can improve harmonic signal strength of speech sounds by suppressing the inharmonic onset noise associated with glottal pulses.

\section{Author details}

${ }^{1}$ NeuroEngineering Laboratory, Dept of Electrical \& Electronic Engineering, University of Melbourne VIC 3010, Australia. ${ }^{2}$ National ICT Australia, c/-

University of Melbourne VIC 3010, Australia. ${ }^{3}$ Centre for Neural Engineering, University of Melbourne, VIC 3010, Australia. ${ }^{4}$ Bionics Institute, East Melbourne VIC 3002, Australia. ${ }^{5}$ Dept. of Pathology, University of Melbourne VIC 3010, Australia.

Published: 8 July 2013 


\section{References}

1. Paolini AG, Clarey JC, Needham K, Clark GM: Fast inhibition alters first spike timing in auditory brainstem neurons. J Neurophysiol 2004, 92(4):2615-2621.

2. Chase $S M$, Young ED: First-spike latency information in single neurons increases when referenced to population onset. PNAS 2007, 104(12):5175-5180

3. Aubie B, Becker S, Faure PA: Computational Models of Millisecond Level Duration Tuning in Neural Circuits. J Neurosci 2009, 9(29):9255-9270.

4. Pollak GD, Gittelman JX, Li N, Xi R: Inhibitory projections from the ventral nucleus of the lateral lemniscus and superior paraolivary nucleus create directional selectivity of frequency modulations in the inferior colliculus: A comparison of bats with other mammals. Hearing Research 2011, 273(12):134-44.

5. Nayagam DAX, Clarey JC, Paolini AG: Powerful, onset inhibition in the ventral nucleus of the lateral lemniscus. J Neurophysiol 2005, 94:1651-1654.

doi:10.1186/1471-2202-14-S1-P148

Cite this article as: Spencer et al:: Onset-inhibition in the auditory brainstem: a potential mechanism for signal enhancement of speechlike sounds. BMC Neuroscience 2013 14(Suppl 1):P148.

\section{Submit your next manuscript to BioMed Central} and take full advantage of:

- Convenient online submission

- Thorough peer review

- No space constraints or color figure charges

- Immediate publication on acceptance

- Inclusion in PubMed, CAS, Scopus and Google Scholar

- Research which is freely available for redistribution

Submit your manuscript at www.biomedcentral.com/submit 